\title{
Effect of Different Levels of Noug (Guizotia Abyssinica) Seed Cake Supplementation on Growth Performance of Doyogena Sheep Fed Rhodes Grass Hay Basal Diet
}

\author{
Lielt Dea $^{1}$, Mekonnen Yirga ${ }^{1 *}$ and Deribe Gemiyo ${ }^{2}$ \\ ${ }^{1}$ Wollo University, College of agriculture, Department of animal sciences, Dessie, Ethiopia \\ ${ }^{2}$ Areka Agricultural research center, Wolyita, Ethiopia
}

\begin{abstract}
The objective of the study was to evaluate the effect of different levels of Noug (Guizotia Abyssinica) seed cake supplementation on feed intake, digestibility and body weight change of Doyogena sheep fed Rhodes grass hay basal diet. The experimental period was 112 days including 90 days of feeding trial and 15 days of adaptation period. Twenty four lambs were assigned into six groups based on their body weight and randomly assigned to four treatments with replication of six sheep to each treatment. The experimental animals were fed on Rhodes grass hay as a basal diet. The treatments were: T1 (Hay ad libtium $+200 \mathrm{~g}$ Wheat bran), T2 (Hay ad libtium +200 $g$ Wheat bran $+150 \mathrm{~g}$ Noug cake), T3 (Hay ad libtium $+200 \mathrm{~g}$ Wheat bran+175 g Noug cake) and T4 (Hay ad libtium $+200 \mathrm{~g}$ Wheat bran+200 $\mathrm{g}$ Noug cake). Fecal samples were collected for 7 days after 3 days of familiarizing lambs to carry fecal bags. Significant $(p<0.001)$ differences were observed in total dry matter, organic matter and crude protein intakes among treatments. Intake increased as level of noug seed cake supplementation increased. The dry matter, organic matter, crude protein digestibility and feed conversion efficiency were significantly $(p<0.001)$ higher with increased level of noug seed cake. Higher $(p<0.001)$ final body weight and average daily body weight gains were observed in sheep supplemented with highest level of Noug seed cake. Based on the results of this study, it can be concluded that supplementation of lambs with $200 \mathrm{~g}$ of Noug seed cake was potentially feasible and economically beneficial.
\end{abstract}

Key words: Digestibility, Doyogena, Intake, Noug seed cake, Wheat bran, Weight gain

DOI: $10.7176 / A L S T / 81-01$

Publication date: August $31^{\text {st }} 2020$

\section{Introduction}

In smallholder agriculture sheep has advantage over large ruminates due to low initial investment requirement, shorter production cycles, faster growth rates and greater environmental adaptability. Sheep can make immediate cash income when needed and important for food security of poor households in tropics and sub tropics (Markos et al., 2006). Sheep in the highlands of Ethiopia are under pressure due to conversion of grazing land into croplands. Although sheep can be kept under harsh and fragmented lands, their potential is constrained mainly by poor quality of local feed sources and poor feeding practices (BoARD, 2005). Feeding poor quality feeds results in slow growth rates, poor fertility, high rates of mortality and consequently reduced productivity of sheep (Getahun, 2001). Hence, supplementing concentrates or high quality forages with low-quality locally available hay is valuable to improve intake and digestibility of roughages (Nurfeta, 2010). Although different studies on supplementation of agro-industrial by-products have been conducted, information pertaining to growth performance of Doyogena sheep supplemented with different level of noug seed (guizotia abyssinica) cakes as protein source is not available. Therefore, the objective of this study was to evaluate the effect of different levels of noug seed cake supplementation on feed intake, digestibility, body weight change and economic benefit of Doyogena sheep

\section{Material and methods \\ Description of the Study Area}

The study was conducted at Areka agricultural research center, situated 300 kilometers south West of Addis Ababa with an altitude of 1850 meters above sea level. The mean annual rainfall and temperature was $1432 \mathrm{~mm}$ and $29.2^{\circ} \mathrm{C}$. The soil type tested was Eutric Nitosole (reddish brown) with pH of 5.7 (Yared et al., 2014).

\section{Experimental Animal and Management}

Twenty four six months old male Doyogena lambs were purchased from local market. The weights of the lambs were taken after overnight fasting. Lambs were blocked based on their live weight into six groups (blocks) each containing four lambs. The four lambs in each block were randomly assigned into four treatments. The age of purchased lambs was determined both by dentition and information from owners. The experimental sheep were 
ear tagged, sprayed using Diazinon 60\% against external parasites and de-wormed with Albendazol bolus against internal parasite following manufacturer's instruction. The lambs were also being vaccinated against Anthrax and Pasteurelosis. To adapt experimental diets and new surroundings, animals were kept for two weeks of acclimatization period and followed by ninety days of feeding period. Lambs were kept in door in individual pens provided with watering and feeding troughs. The experimental animals were carefully observed for the occurrence of any illness and records were taken for any physiological disorder throughout the experimental period.

\section{Feed and Feeding Management}

The basal diet of the experiment was Rhodes grass hay. To improve feed intake, grass hay was chopped into 4-5 $\mathrm{cm}$ and offered ad libitum $(\approx 20 \%$ refusal). Hay offered and corresponding refusals were weighed and recorded each day before morning feeding. Fresh and clean water was accessed ad libitum. Noug (guizota abyssinica) seed cake and wheat bran was purchased from Damota Wolayta farmers' co-operative union and stored properly in safe place till the end of the feeding period. Rhodes hay and mixture of wheat bran and Noug seed cake was offered separately. Wheat bran and Noug seed cake mixtures were offered in two equal portions at 02:00 and 10:00 AM local time daily. Feed intake was recorded daily whereas body weight of animals was taken every week before morning feeding with hanging balance (50 kg capacity of $100 \mathrm{gm}$ precision).

\section{Experimental Design and Treatments}

The experimental design was randomized complete block design (RCBD) with four treatments and six replications. Lambs were blocked into six groups based on their initial body weight and randomly assigned to the four dietary treatments.

$\mathrm{T} 1=$ Rhodes Grass hay ad libtium $+200 \mathrm{~g}$ wheat bran (Control)

$\mathrm{T} 2=$ Rhodes hay ad libtium $+200 \mathrm{~g}$ Wheat bran $+150 \mathrm{~g}$ Noug cake

$\mathrm{T} 3=$ Rhodes hay ad libtium $+200 \mathrm{~g}$ Wheat bran $+175 \mathrm{~g}$ Noug cake

$\mathrm{T} 4=$ Rhodes hay ad libtium $+200 \mathrm{~g}$ Wheat bran $+200 \mathrm{~g}$ Noug cake

\section{Data Collection and Chemical Analysis Feed intake and body weight change}

Daily feed offered and refusals were collected from each lamb throughout the experimental period. Daily mean feed intake was measured as differences between offered and refused feeds. In the beginning of the feeding trial an average weight of two consecutive measurements was taken as an initial body weight. Weight of each animal was taken every seven days after overnight fasting. At the end of the treatment weight gain was calculated as the difference between final and initial body weights. The daily body weight gains were calculated as the difference between final body weight and initial body weight divided by number of feeding days. The feed conversion efficiency of experimental animals was determined by dividing the average daily body weight gain to the amount of feed consumed.

\section{Digestibility}

The digestibility trial was conducted at the end of the feeding trial. To collect sample for digestibility trial, experimental animals were fitted with fecal bags for three days of acclimatization period to fecal collection bags prior to total collection of faeces for 7 consecutive days. Each day's total fecal excretion of each animal was weighed and $20 \%$ of sub-sampled was stored frozen at $-20^{\circ} \mathrm{C}$. After a week, the seven days sample was mixed to make a single weekly composite fecal sample. The daily total fecal excretion collected for seven days was used for the determination of digestibility co-efficient.

\section{Chemical analysis}

Samples of feed offered, refusals and feces was chemically analyzed for Dry matter (DM), Ash and Organic matter (OM) based on the method of Association of Analytical Chemistry (1990); Crude protein (CP), Neutral detergent fibers (NDF), acid detergent fiber (ADF), and acid detergent lignin (ADL) contents based on the method of Van Soest and Robertson (1985) at Debre Birhan Agricultural Research Centers laboratories.

\section{Partial Budget Analysis}

The partial budget analysis was calculated to determine the profitability of different treatments. The economic analysis included calculations of variable costs and benefits. At the end of the experiment, the selling price of each experimental sheep was determined by inviting well experienced sheep dealers who know the prevailing market price of different size of sheep in the area. The selling price difference of sheep before and after experimental period was considered as total return (TR) in the partial budget analysis. For the calculation of the total variable costs (TVC), the expenditures incurred on various feedstuffs were taken into consideration. The cost of the feeds was computed by multiplying the actual feed intake for the whole feeding period with the prevailing prices.

Net income (NI) or net benefit was calculated as the amount of money left when total variable cost (TVC) was subtracted from total return (TR) or gross field benefit. The change in net income $(\Delta \mathrm{NI})$ was calculated as the difference between the change in total return $(\Delta \mathrm{TR})$ and the change in total variable cost $(\Delta \mathrm{TVC})$ and was 
calculated as: $\Delta \mathrm{NI}=\Delta \mathrm{TR}-\Delta \mathrm{TVC}$. The marginal rate of return (MRR) measures the increase in net income $(\Delta \mathrm{NR})$ associated with each additional unit of expenditure ( $\Delta$ TVC). This is expressed as MRR $=\Delta \mathrm{NR} / \Delta \mathrm{TVC}$

Statistical Analysis

The analysis of variance (ANOVA) of data on feed intake, body weight change, and digestibility were run using the general linear model (GLM) procedure of SAS (SAS, 2008). Mean separation was employed using Tukey's adjustment at $\mathrm{P}<0.05$. The statistical model used for data analysis was $Y_{i j}=\mu+T_{i}+B_{j}$ $+e_{i j}$; where; $Y_{i j}$ is observation in the $j^{\text {th }}$ block and $i^{\text {th }}$ treatment; $\mu$ the overall mean; $T_{i}$ the $i^{\text {th }}$ treatment effect; $B_{j}$ the $\mathrm{j}^{\text {th }}$ block effect; and $\mathrm{e}_{\mathrm{ij}}$ the random error.

\section{Results and Discussion}

Chemical composition and dry matter Intake

Chemical composition of treatment feeds, dry matter and nutrient intake of sheep fed Rhodes grass hay supplemented with different levels of Noug cake is presented in Tables 1 and 2. Rhodes grass hay could be characterized as nutritionally poor to fulfill the maintenance requirement of sheep for proper microbial function (Van Soest, 1982) due to its low CP and high fiber fraction contents. The CP content of wheat bran was in range with 8-14\% reported by McDonald et al. (2010).

Table 1. Chemical composition of treatment feeds

\begin{tabular}{lcccccc}
\hline Ingredients/Treatments & DM \% & OM \% & CP \% & NDF\% & ADF\% & ADL\% \\
\hline Noug Cake & 94.00 & 93.62 & 28.25 & 58.46 & 39.13 & 11.24 \\
Wheat bran & 92.00 & 96.74 & 13.78 & 35.46 & 23.91 & 5.52 \\
Rhodes Grass hay & 92.00 & 94.57 & 4.20 & 79.36 & 60.87 & 16.67 \\
Treatments & & & & & & \\
T1 & 92.00 & 96.74 & 13.78 & 35.46 & 23.9 & 5.54 \\
T2 & 92.86 & 95.08 & 20.06 & 45.44 & 30.52 & 8.00 \\
T3 & 92.93 & 95.26 & 20.61 & 46.32 & 31.10 & 8.24 \\
T4 & 93.00 & 95.20 & 21.10 & 47.11 & 31.60 & 8.41 \\
\hline
\end{tabular}

DM = Dry matter $;$ OM = Organic matter $C P=$ Crude protein $; N D F=$ Neutral detergent fiber $;$ ADF $=$ Acid detergent fiber; $A D L=$ Acid detergent lignin; $T 1=$ Hay ad libtium $+200 \mathrm{~g}$ Wheat bran; $T 2=$ Hay ad libtium + $200 \mathrm{~g}$ Wheat bran $+150 \mathrm{~g}$ Noug seed cake; $\mathrm{T3}=$ Hay ad libtium $+200 \mathrm{~g}$ Wheat bran $+175 \mathrm{~g}$ Noug seed cake; $T 4=$ Hay ad libtium $+200 \mathrm{~g}$ Wheat bran $+200 \mathrm{~g}$ Noug seed cake.

The mean basal and supplemental feed intakes were 613.5 and 307.4 grams per head per day. Noug seed cake supplementation had resulted in great variations in dry matter and other nutrient intake of lambs. Increased supplementation level of Noug cake has increased dry matter intake. Organic matter and crude protein intakes consistently increased as level of noug cake supplementation increased and decreased as supplementation level reduced. The total daily dry matter intake was higher $(\mathrm{p}<0.001)$ in lambs supplemented with noug cake because noug cake improves energy due to the supplementary role of protein on energy and in line with the findings of Tadesse and Zelalem (2003). Report of Gemeda et al., (2003) also denoted that increasing proportion of noug seed cake increases both feed intake and body weight gain. This implies that supplementation of low protein quality feeds with noug seed cake significantly improves total dry matter intake without affecting the intake of basal diet. 
Table 2: Dry matter and nutrient intake of sheep fed Rhodes grass hay supplemented with different levels of Noug seed cake

\begin{tabular}{|c|c|c|c|c|c|c|c|}
\hline \multirow{2}{*}{ Intake } & \multicolumn{7}{|c|}{ Treatments } \\
\hline & $\mathrm{T} 1$ & $\mathrm{~T} 2$ & T3 & $\mathrm{T} 4$ & Mean & SEM & SL \\
\hline \multicolumn{8}{|l|}{ Dry matter intake } \\
\hline Basal feed (g/d) & 617.00 & 613.00 & 612.70 & 611.40 & 613.50 & 42.20 & NS \\
\hline Supplement (g/d) & $184.00^{\mathrm{d}}$ & $325.00^{c}$ & $348.50^{\mathrm{b}}$ & $372.00^{\mathrm{a}}$ & 307.40 & 0.00 & $* * *$ \\
\hline Total DM (g/d) & $801.00^{\mathrm{d}}$ & $938.00^{c}$ & $961.20^{\mathrm{b}}$ & $983.40^{\mathrm{a}}$ & 920.85 & 42.20 & $* * *$ \\
\hline Total DM $\left(\mathrm{g} / \mathrm{kg} \mathrm{W}^{0.75}\right)$ & $95.60^{\mathrm{b}}$ & $101.40^{\mathrm{a}}$ & $96.25^{\mathrm{b}}$ & $95.10^{\mathrm{b}}$ & 97.10 & 6.82 & $* * *$ \\
\hline $\mathrm{DM}(\% \mathrm{BW})$ & $4.71^{a}$ & $4.84^{\mathrm{a}}$ & $4.47^{b}$ & $4.37^{b}$ & 4.60 & 0.37 & $* * *$ \\
\hline Total OM intake $(\mathrm{g} / \mathrm{d})$ & $837.36^{\mathrm{d}}$ & $964.96^{c}$ & $991.54^{b}$ & $1015.20^{\mathrm{a}}$ & 952.26 & 41.70 & $* * *$ \\
\hline Total CP intake $(\mathrm{g} / \mathrm{d})$ & $54.00^{\mathrm{d}}$ & $93.79^{c}$ & $99.86^{\mathrm{b}}$ & $106.45^{\mathrm{a}}$ & 88.53 & 2.10 & $* * *$ \\
\hline Total NDF intake $(\mathrm{g} / \mathrm{d})$ & $600.75^{\mathrm{c}}$ & $700.25^{b}$ & $701.72^{b}$ & $719.62^{a}$ & 680.58 & 38.30 & $* * *$ \\
\hline Total ADF intake (g/d) & $447.59^{b}$ & $517.48^{a}$ & $516.71^{\mathrm{a}}$ & $520.41^{\mathrm{a}}$ & 500.54 & 29.60 & $* * *$ \\
\hline Total ADL intake (g/d) & $122.97^{b}$ & $143.58^{\mathrm{a}}$ & $143.21^{\mathrm{a}}$ & $143.34^{\mathrm{a}}$ & 138.27 & 7.20 & $* * *$ \\
\hline MJ ME & $13.15^{\mathrm{d}}$ & $15.15^{\mathrm{c}}$ & $15.57^{\mathrm{b}}$ & $15.94^{\mathrm{a}}$ & 14.95 & 0.66 & $* * *$ \\
\hline
\end{tabular}

a,b,c,d Means with different superscripts in a row are significantly different.

$\mathrm{NS}=$ non significance level, $\left.\left.\left.{ }^{*}=\mathrm{p}<0.05\right) ; * *=\mathrm{p}<0.01\right) ; * * *=\mathrm{p}<0.001\right) ; \mathrm{DM}=$, dry matter; OM= organic matter; $\mathrm{CP}=$ crude protein $\mathrm{NDF}=$ neutral detergent fiber; $\mathrm{ADF}=$ acid detergent fiber; $\mathrm{ADL}=$ acid detergent lignin; $\mathrm{SEM}=$ standard error of mean; $\mathrm{SL}=$ significance level; $\mathrm{T} 1=$ Hay $+200 \mathrm{~g}$ Wheat bran; $\mathrm{T} 2=$ Hay $+200 \mathrm{~g}$ Wheat bran +150 $\mathrm{g}$ Noug cake; T3 = Hay $+200 \mathrm{~g}$ Wheat bran $+175 \mathrm{~g}$ Noug cake; T4 = Hay $+200 \mathrm{~g}$ Wheat bran $+200 \mathrm{~g}$ Noug cake.

\section{Digestible Nutrient Intake and Digestibility}

Total dry matter and organic matter digestibility was higher $(\mathrm{p}<0.001)$ in animals supplemented with Noug cake (Table 7). The digestible DM and OM intake showed that there were significant $(\mathrm{p}<0.001)$ differences in treatments supplemented with noug cake than non-supplemented groups. This result is in agreement with Almaz (2008) who reported an increased digestible DM intake when lambs supplemented with protein rich sources. However, there is no $(\mathrm{P}>0.05)$ difference in digestible nutrient intake of treatments with 175 and $200 \mathrm{~g}$ noug cake supplemented groups. The CP digestible intake had significant $(\mathrm{p}<0.001)$ difference as noug cake level increased. The same result has been confirmed by Fentie (2007) for increased level of noug cake on Farta sheep supplemented with wheat bran, noug seed cake and their mixture. The result showed significant $(p<0.001)$ difference on digestible nutrient intake of NDF, ADF and ADL. However, reports of Fentie (2007) showed that there is no significance $(\mathrm{P}>0.05)$ difference on NDF and ADF digestible nutrient intake. Animals supplemented with 175 and $200 \mathrm{~g} \mathrm{NSC} /$ head per day did not show significant ( $\mathrm{p}>0.05)$ differences in DM digestibility. The trend in CP level increased due to the increased level of NSC. However, the CP digestibility result of this study $(67.91 \%)$ is lower than 79.69\% reported by Abebaw (2007) for sheep supplemented with rice bran, noug seed cake and their mixtures.

\section{Body Weight Change}

Supplementation of noug seed cake showed significant difference in both average daily weight gain and feed conversion efficiency (Table 8). The average daily body weight gain, final body weight gain and FCE of sheep supplemented with wheat bran and noug seed cake was significantly different $(p<0.001)$ among treatments and the control. Body weight gain (BWG) was increased as CP intake increased. Animals supplemented with 175 and 200 g NSC/head/day. This indicates that the supplements of NSC in 175 and $200 \mathrm{~g} \mathrm{NSC/head/day} \mathrm{did} \mathrm{not} \mathrm{show}$ significant variation $(\mathrm{p}<0.001)$ on final body weight gain and average daily body weight gain. The average daily weight gain result obtained in this study is comparable with $(51.1-63.3 \mathrm{~g})$ daily body weight gain reported by Almaz (2008) who reported for a sheep supplemented with $300 \mathrm{~g}$ of Atella, NSC and their mixture while lower 
than (70.11-82.44g) daily body weight gain reported by Fentie (2007) for Farta sheep supplemented with wheat bran, NSC and their mixture. The current finding is higher than (37.88-57.77g) the report of Abebaw (2007) for Farta sheep supplemented with rice bran, noug seed cake and their mixtures at various proportions. As the level of Noug cake increased the FCE also increased $(\mathrm{T} 2<\mathrm{T} 3<\mathrm{T} 4)$ and the trend was similar across treatments. Feed conversion efficiency is directly proportional to feed intake and faster digestibility which could have been facilitated by rumen microbial action. This result agree with reports of Mulugeta and Gerbehiwot (2013) who noted increased body weight gain and FCE as protein source supplement of increased.

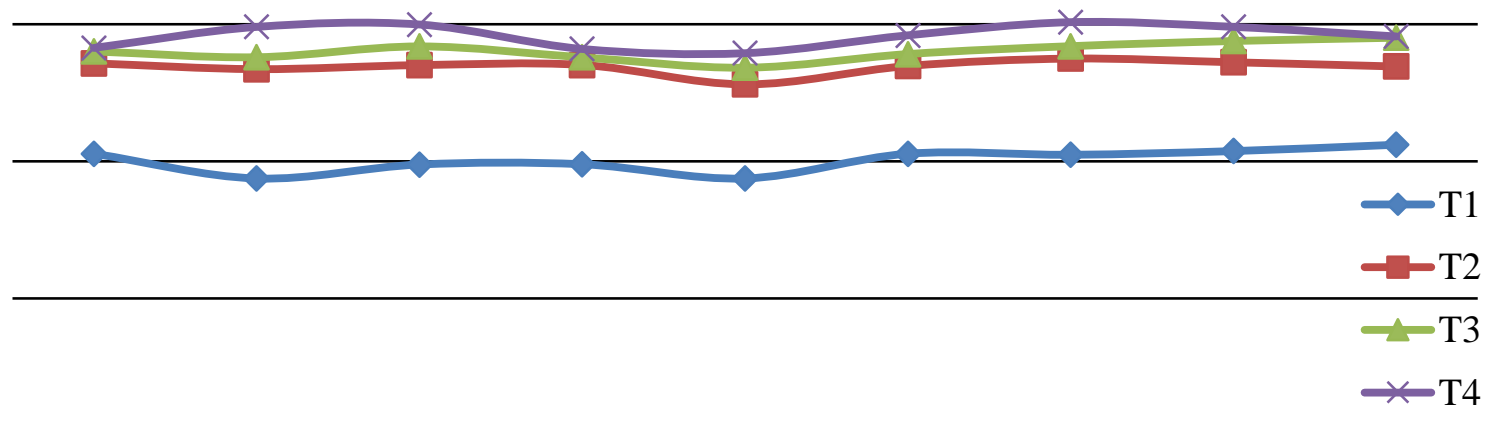

\section{Experimental period (days)}

Figure 1: Trends in dry matter intake or עoyogena sneep consumea knodes grass hay supplemented with different levels of noug cake

Table 3: Digestible nutrient intake and percent Nutrient digestibility of Doyogena sheep fed on Rhodes grass hay supplemented with different levels of noug seed cake.

\begin{tabular}{|c|c|c|c|c|c|c|c|}
\hline \multirow[b]{2}{*}{ Parameter } & \multicolumn{7}{|c|}{ Treatments } \\
\hline & $\mathrm{T} 1$ & $\mathrm{~T} 2$ & $\mathrm{~T} 3$ & $\mathrm{~T} 4$ & Mean & SEM & SL \\
\hline \multicolumn{8}{|c|}{ Digestible nutrient Intake (g/day) } \\
\hline $\mathrm{DM}$ & $495.82^{c}$ & $599.07^{\mathrm{b}}$ & $619.59^{a}$ & $621.74^{\mathrm{a}}$ & 584.05 & 30.00 & $* * *$ \\
\hline $\mathrm{OM}$ & $562.62^{\mathrm{c}}$ & $666.33^{\mathrm{b}}$ & $696.16^{\mathrm{a}}$ & $701.81^{\mathrm{a}}$ & 657.48 & 30.55 & $* * *$ \\
\hline $\mathrm{CP}$ & $19.57^{\mathrm{d}}$ & $61.28^{c}$ & $65.84^{\mathrm{b}}$ & $71.41^{\mathrm{a}}$ & 54.52 & 1.72 & $* * *$ \\
\hline NDF & $347.65^{\mathrm{c}}$ & $385.96^{\mathrm{b}}$ & $433.39^{\mathrm{a}}$ & $425.88^{\mathrm{a}}$ & 398.22 & 27.10 & $* * *$ \\
\hline $\mathrm{ADF}$ & $234.12^{\mathrm{c}}$ & $247.49^{\mathrm{b}}$ & $289.88^{\mathrm{a}}$ & $285.48^{\mathrm{a}}$ & 264.25 & 22.43 & $* * *$ \\
\hline ADL & $73.18^{\mathrm{c}}$ & $75.90^{\mathrm{c}}$ & $91.38^{\mathrm{a}}$ & $86.19^{b}$ & 81.66 & 5.66 & $* * *$ \\
\hline MJ ME & $8.88^{\mathrm{c}}$ & $10.46^{\mathrm{b}}$ & $10.92^{\mathrm{a}}$ & $11.02^{\mathrm{a}}$ & 10.32 & 0.48 & $* * *$ \\
\hline \multicolumn{8}{|c|}{ Digestibility (\%) } \\
\hline $\mathrm{DM}$ & $60.80^{c}$ & $63.30^{\mathrm{b}}$ & $64.57^{\mathrm{a}}$ & $65.62^{\mathrm{a}}$ & 63.58 & 1.98 & $* * *$ \\
\hline OM & $66.45^{\mathrm{d}}$ & $68.49^{c}$ & $70.32^{\mathrm{b}}$ & $71.73^{\mathrm{a}}$ & 69.25 & 1.68 & $* * *$ \\
\hline
\end{tabular}




\begin{tabular}{|l|l|l|l|l|l|l|l|}
\hline $\mathrm{CP}$ & $35.84^{\mathrm{c}}$ & $65.15^{\mathrm{b}}$ & $65.77^{\mathrm{b}}$ & $67.91^{\mathrm{a}}$ & 58.67 & 2.77 & $* * *$ \\
\hline $\mathrm{NDF}$ & $56.51^{\mathrm{c}}$ & $54.71^{\mathrm{d}}$ & $61.64^{\mathrm{b}}$ & $62.96^{\mathrm{a}}$ & 58.955 & 2.27 & $* * *$ \\
\hline $\mathrm{ADF}$ & $51.05^{\mathrm{c}}$ & $47.34^{\mathrm{d}}$ & $56.17^{\mathrm{b}}$ & $57.93^{\mathrm{a}}$ & 53.12 & 2.67 & $* * *$ \\
\hline $\mathrm{ADL}$ & $58.26^{\mathrm{b}}$ & $52.43^{\mathrm{c}}$ & $63.86^{\mathrm{a}}$ & $63.24^{\mathrm{a}}$ & 59.45 & 2.29 & $* * *$ \\
\hline
\end{tabular}

$a_{\text {a-d }}=$ means with different superscripts in a row are significantly different. $*=(P<0.05) ; * *=(P<0.01) ; * * *$ $=(P<0.001) ; D M=$ dry matter $; O M=$ organic matter $; C P=$ crude protein $; N D F=$ neutral detergent fiber $; A D F=$ acid detergent fiber; $A D L=$ acid detergent lignin; $S E M=$ standard error of mean; $S L=$ significance level; $T 1=$ Hay $+200 \mathrm{~g}$ Wheat bran; T2 = Hay $+200 \mathrm{~g}$ Wheat bran $+150 \mathrm{~g}$ Noug cake; T3 = Hay $+200 \mathrm{~g}$ Wheat bran + $175 \mathrm{~g}$ Noug cake; $\mathrm{T} 4=$ Hay $+200 \mathrm{~g}$ Wheat bran $+200 \mathrm{~g}$ Noug cake.

Table 4: Body weight changes of sheep fed Rhodes grass hay supplemented with different levels of Noug Cake.
Body weight changes
Treatments
Mean SEM SL

\begin{tabular}{|c|c|c|c|c|c|c|c|}
\hline & & & & & & & \\
\hline & $\mathrm{T} 1$ & $\mathrm{~T} 2$ & $\mathrm{~T} 3$ & $\mathrm{~T} 4$ & & & \\
\hline Initial body weight $(\mathrm{kg})$ & 16.40 & 16.70 & 16.70 & 16.50 & 16.59 & 1.71 & $\mathrm{NS}$ \\
\hline Final body weight (kg) & $17.13^{\mathrm{b}}$ & $19.71^{\mathrm{ab}}$ & $21.58^{\mathrm{a}}$ & $22.58^{\mathrm{a}}$ & 20.25 & 1.84 & $* * *$ \\
\hline Total weight change (kg) & $0.70^{c}$ & $3.03^{\mathrm{b}}$ & $4.83^{\mathrm{a}}$ & $6.06^{\mathrm{a}}$ & 3.66 & 0.76 & $* * *$ \\
\hline Average daily gain (g) & $7.78^{c}$ & $33.70^{\mathrm{b}}$ & $53.70^{\mathrm{a}}$ & $67.40^{\mathrm{a}}$ & 40.65 & 8.50 & $* * *$ \\
\hline FCE (g ADG/g DMI) & $0.01^{\mathrm{d}}$ & $0.04^{\mathrm{c}}$ & $0.06^{\mathrm{b}}$ & $0.07^{\mathrm{a}}$ & 0.04 & 0.0023 & $* * *$ \\
\hline
\end{tabular}

$\overline{a-d}=$ means with different superscripts in a row are significantly different. $N S=$ non significant level, ${ }^{*}=(P<$ $0.05) ; * *=(P<0.01) ; * * *=(P<0.001) D M=$, dry matter $;$ OM= organic matter $C P=$ crude protein $; N D F=$ neutral detergent fiber; $A D F=$ acid detergent fiber; $A D L=$ acid detergent lignin; $S E M=$ standard error of mean; $S L=$ significance level; $T 1=$ Hay $+200 \mathrm{~g}$ Wheat bran; $T 2=$ Hay $+200 \mathrm{~g}$ Wheat bran $+150 \mathrm{~g}$ Noug cake; T3 = Hay $+200 \mathrm{~g}$ Wheat bran $+175 \mathrm{~g}$ Noug cake; $T 4=$ Hay $+200 \mathrm{~g}$ Wheat bran $+200 \mathrm{~g}$ Noug cake.

Figure 2 indicates that there is no weight loss even in control group supplied with $200 \mathrm{~g}$ of wheat bran as energy source that could satisfy the maintenance requirement of sheep. The same result was reported by Mulugeta and Gerbehiwot (2013) where weight loss is not recorded in the control group.

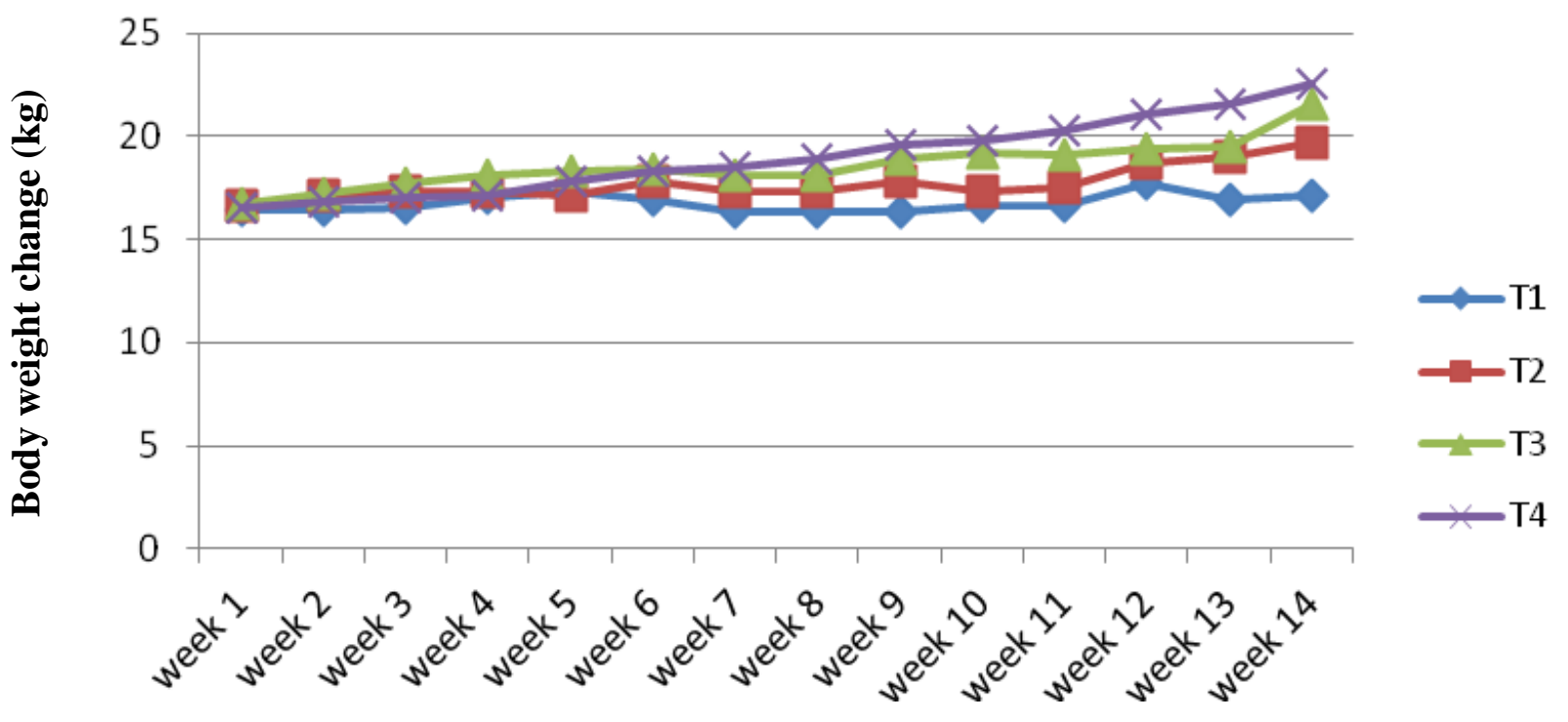

\section{Experimental period in weeks}

Figure 3: Trends of body weight change of Doyogena sheep fed Rhodes grass hay supplemented with different levels of Noug seed cake. 


\section{Partial Budget Analysis}

Partial budget analysis of Doyogena Sheep fed Rhodes hay basal diet supplemented with wheat bran and different levels of noug cake is presented in Table 9. Total return from animal sell was increased as a level of noug seed cake supplementation increase. This is related with improved energy and protein quality of consumed feed leading to increased body weight gain and improved body condition of the sheep. Based on the total variable costs, purchasing and selling prices of sheep, the highest total return was gained from sheep supplemented with $200 \mathrm{~g}$ of noug seed cake (T4). The highest net return and marginal rate of return was obtained from T4 due to optimum level of energy and protein supplementation resulting in higher average body weight gain and higher selling.

Table 9: Partial budget analysis for Doyogena Sheep fed on Rhodes hay and supplemented with wheat bran and different levels of noug cake at different level.

\begin{tabular}{lllll}
\hline & \multicolumn{4}{c}{ Treatments } \\
Variables & T1 & T2 & T3 & T4 \\
\hline No of animals & 6 & 6 & 6 & 6 \\
Purchasing price (ETB/sheep) & 850.00 & 870.00 & 855.00 & 865.00 \\
Total hay consumed (kg/sheep) & 55.50 & 55.23 & 55.00 & 55.14 \\
Total concentrate consumed (kg/sheep) & 12.42 & 25.10 & 28.00 & 29.34 \\
Total feeds Consumed (kg/sheep) & 67.92 & 80.33 & 83.00 & 84.48 \\
Cost of hay (ETB/kg) & 166.50 & 165.69 & 165.00 & 165.42 \\
Cost of concentrate (ETB/consumption) & 74.52 & 152.60 & 170.00 & 179.00 \\
Total feed cost or TVC (ETB/consumption) & 241.02 & 318.29 & 335.00 & 344.42 \\
$\Delta \mathrm{TVC}(\mathrm{ETB})$ & 0.00 & 77.27 & 93.98 & 103.40 \\
Sheep selling price or GR (ETB/sheep) & 1000.00 & 1200.00 & 1300.00 & 1500.00 \\
$\Delta \mathrm{GR}$ & 0.00 & 200.00 & 300.00 & 500.00 \\
Total return TR & 150.00 & 330.00 & 445.00 & 635.00 \\
$\Delta \mathrm{TR}$ & 0.00 & 180.00 & 295.00 & 485.00 \\
NI=TR-TVC & -91.02 & 11.71 & 110.00 & 290.58 \\
$\Delta \mathrm{NI}=\Delta \mathrm{TR}-\Delta \mathrm{TVC}$ & 0.00 & 102.73 & 201.02 & 381.60 \\
MRR or $(\Delta \mathrm{NI} / \Delta \mathrm{TVC}$ (ETB) & 0.00 & 1.33 & 2.14 & 3.70 \\
\hline
\end{tabular}

$T V C=$ Total variable cost $; G R=$ Gross return; $T R=$ Total return; $N R=$ Net return; $M R R=$ Marginal rate of return; $E T B=$ Ethiopian Birr; $T 1=$ Hay $+200 \mathrm{~g}$ Wheat bran; $T 2=$ Hay $+200 \mathrm{~g}$ Wheat bran $+150 \mathrm{~g}$ Noug cake; $T 3=$ Hay $+200 \mathrm{~g}$ Wheat bran $+175 \mathrm{~g}$ Noug cake; $T 4=$ Hay $+200 \mathrm{~g}$ Wheat bran $+200 \mathrm{~g}$ Noug cake

The result of this study suggests that supplementation of Rhodes hay with $200 \mathrm{~g}$ of noug seed cake is potentially more feasible and economically beneficial than the other supplements. This result is in agreement with the result of Mulugeta and Gebrehiwot (2013) on sheep supplemented with wheat bran and sesame cake. From the result of this study, it can be concluded that supplementation of Rhodes grass hay with $200 \mathrm{~g}$ wheat bran and 200g of NSC (T4) could be reasonably enough to improve feed dry matter and nutrient intake, nutrient digestibility, live weight change and feed conversion efficiency.

\section{References}

Abebaw, N. and Solomon, M. 2008. Feed intake, digestibility and body weight change in Farta sheep fed hay supplemented with rice bran and Noug seed (Guizotia abysinica) meal. Tropical Animal Health and Production

Almaz, A. 2008. Supplementation of dried atella, noug seed (Guizotia abyssinica) cake and their mixtures on feed intake, digestibility and live weight change of local sheep fed finger millet (Eleusine coracana) straw basal diet. MSc Thesis. Haramaya University, Haramaya, Ethiopia

BoARD (Bureau of Agriculture and Rural Development). 2005. Animal feeding strategy. Amhara National Regional State. Bahir Dar. Ethiopia. 
Fentie, B. 2007. Effect of supplementation of hay with Noug seed cake (guizotia abyssinica), Wheat bran and their mixtures on feed utilization, digestibility and live weight change in farta sheep. MSc Thesis, Haramaya University, Haramaya, Ethiopia.

Gemeda, D., Takele, K., Ulfina, G. and Solomon, A. 2003. Growth performance of weaned Horro lambs feed basal diet of barley straw and supplemented with different levels of concentrates. pp.355-362. In: Proceeding of the 11th Annual Conference of the Ethiopian Society of Animal Production, August 23-28 2003. Addis Ababa, Ethiopia.

Getahun, L. 2001. Growth pattern and carcass characteristics of Somali and Mid-Rift valley goats. MSc Thesis Haremaya University, Haremaya, Ethiopia. pp106

Mulugeta, F. and Gebrehiwot, T. 2013. Effect of sesame cake supplementation on feed intake, body weight gain, feed conversion efficiency and carcass parameters in the ration of sheep fed on wheat bran and teff (Eragrostis tef) straw. Momona Ethiopian Journal of Science (MEJS), 5(1): 89-106, 2013, ISSN: 2220$184 \mathrm{X}$.

Nurfeta, A. 2010. Feed intake, digestibility, nitrogen utilization and body weight change of sheep consuming wheat straw supplemented with local agricultural and agro-industrial by-products. Tropical Animal Health and Production, 42: 815-824.

Van Soest, P.J. and Robertson, J.B. 1985. Analysis of forages and fibrous feeds. A laboratory manual for animal science, Vol. 613. Cornell University, Ithaca, New York.

Van Soest, P. J. 1982. Nutritional Ecology of the Ruminants O and B books, Corvallis, Oregon, USA. pp. 374.

Yared, D., Tewodros, M. and Asfaw, K. 2014. Development of high yielding Taro (Colocacia esculenta L.) Variety for mid altitude growing areas of Southern Ethiopia. Journal of Plant Sciences 2014; 2(1): 50-54 